This item was submitted to Loughborough's Research Repository by the author.

Items in Figshare are protected by copyright, with all rights reserved, unless otherwise indicated.

\title{
The impact of special economic zones on electricity intensity of firms
}

\author{
PLEASE CITE THE PUBLISHED VERSION \\ https://doi.org/10.5547/01956574.39.SI1.rdav \\ PUBLISHER
}

International Association for Energy Economics

VERSION

AM (Accepted Manuscript)

PUBLISHER STATEMENT

This paper was accepted for publication in the journal Energy Journal and the definitive published version is available at https://doi.org/10.5547/01956574.39.SI1.rdav

\section{LICENCE}

CC BY-NC-ND 4.0

\section{REPOSITORY RECORD}

Davies, Ronald B., Huw Edwards, and Arman Mazhikeyev. 2019. "The Impact of Special Economic Zones on Electricity Intensity of Firms". figshare. https://hdl.handle.net/2134/27498. 


\title{
The Impact of Special Economic Zones on Electricity Intensity of Firms*
}

\author{
Ronald B. Davies ${ }^{\dagger}$ \\ (University College Dublin) \\ T. Huw Edwards \\ (Loughborough University) \\ Arman Mazhikeyev \\ (University College Dublin) \\ Working Paper: Comments Welcome
}

August 3, 2017

\begin{abstract}
In light of concerns over the environmental impact of Special Economic Zones located in developing countries, where environmental regulation is weak, we analyse the electricity intensity of firms in SEZs. We use firm level data from Africa and Asia, and we find that SEZ firms have higher electricity intensity as opposed to non-SEZ firms. If they also face higher fiscal, financial or environmental regulations, the electricity intensity of firms in SEZs increases by a greater rate as opposed to non-SEZ firms. As such, establishing SEZs may have significant environmental implications
\end{abstract}

JEL classification: F14; J16.

Keywords: Energy Intensity; Special Economic Zones.

${ }^{*}$ This project has received funding from the European Union's Seventh Framework Programme for research, technological development and demonstration under grant agreement no. 613504. All errors are our own.

${ }^{\dagger}$ Corresponding author: University College Dublin. Email: ronbdavies@gmail.com. 


\section{Introduction}

Special Economic Zones (SEZs) have become a prevalent policy instrument for promoting export oriented economic growth. Between 1986 to 2014, the number of SEZs went from 176 to over 4000 (Farole, 2011; The Economist, 2015). By offering preferential policies such as lower export/import barriers or reduced tax rates, SEZs are intended to provide an environment that attracts FDI, encourages skill upgrading, and the adoption of new technologies, all of which can help developing economies to diversify their production base into manufacturing. For example, in part due to its use of SEZs, Costa Rica increased the share of manufacturing in its exports from $10 \%$ in 1999 to $61 \%$ by 2013 (CID, 2015). With the explosion of SEZs in the developing world (60\% are in Asia-Pacific countries with another $20 \%$ in the Middle East and Africa), the World Bank (2008) reports that over $40 \%$ of global exports are done by SEZs in the developing world. Alongside this increase in manufacturing comes the potential for significant environmental damage. Studies like Eskeland and Harrison (2003) and Cole et al. (2005) show that there is a strong link between activities of manufacturing firms and greenhouse gas (GHG) emissions resulting from intensive energy use by firms. In particular, as discussed by the ILO (1998), because most SEZs are in developing countries where environmental regulations are relatively weak this raises the concern that SEZs may have significant environmental consequences. In this paper, we use data on over 11,000 manufacturing firms across 32 developing countries to examine whether firms in SEZs are indeed more energy intensive relative to their counterparts. Focusing on electricity, for which data are available, we find that even after controlling for factors such as productivity and industry, firms in SEZs are approximately $4 \%$ more electricity intensive than comparable non-SEZ firms. In particular, we find that this gap is higher when firms face greater financial barriers, suggesting that SEZ firms (which typically report better access to funding) may be upgrading to more modern yet energy-intensive technologies.

While most of the literature on SEZs studies productivity (World Bank 2008), backward and forward linkages (Din, 1994), exporting behaviour (Davies and Mazhikeyev, 2015), 
working conditions (Milberg and Amengual, 2008), welfare gains (Hamilton and Svensson, 1982), or compares the experiences of implementation of policy in different regions (Aci, et al., 2009; Cling et al., 2005; Farole, 2011, World Bank 2008, KPMG, 2011), the environmental aspects of SEZs have not received significant attention. According to Farole (2011) and Zeng (2015), SEZs are geographically distinct territories where (foreign and local) firms can benefit from lower export fees, taxes, import tariffs, and less bureaucracy, inspections and paperwork. In SEZs, therefore, firms can produce, export, and import more easily and quickly, compared to firms in other non-SEZ parts of a country. This gives an advantage for SEZ-based firms, potentially leading to an inter-firm reallocation of production a la Melitz (2003) in favor of SEZs. In fact, we do observe that firms in SEZs are larger and export more often. This greater size then has knock-on environmental consequences depending on the relative emissions of SEZ and non-SEZ firms. As emissions data is typically unavailable, as with the bulk of the literature, we focus on energy intensity which, as demonstrated by Becker and Henderson (2000), Greenstone (2002), and Broner, et al., (2013) is correlated with GHG emissions. Thus our aim here is to compare the energy intensity, and specifically the electricity intensity (electricity expenditures relative to sales) of SEZ and non-SEZ firms 1

A priori, one can envisage a number of potentially conflicting differences between SEZ firms and non-SEZ firms that can affect their electricity intensity. First, if SEZ firms have more modern technologies, these may reduce the overall energy needs of production. Alternatively, if these more modern and more automated plants use electricity rather than coal or oil, this would increase electricity intensity $\left.\right|^{2}$ Further, SEZ firms may produce a different mix of products. Note that these possibilities may well be linked to a firm's funding opportunities since they represent a costly change in technology. Second, if an SEZ leads a firm alter its product mix so that it manufactures more energy intensive goods within its industry, then

\footnotetext{
${ }^{1}$ Our focus on electricity is driven by data availability. We acknowledge that this is nevertheless only one source of energy and that the results must be interpreted in that light.

${ }^{2}$ Roy and Yasar (2015) find that exporting results in a shift from other energy sources towards electricity.
} 
SEZ firms may be more electricity intensive compared to their non-SEZ counterparts. Third, if SEZs are dominated by foreign multinationals seeking lower environmental regulation due to their energy use, firms in SEZs may be more energy intensive $3^{3}$ Finally, it may be that electricity provision in SEZs is more reliable than outside of such zones, leading to higher reliance on this energy type (and perhaps energy overall). Therefore the net effect of SEZs on electricity intensity is an open question.

Against this backdrop, we estimate the electricity intensity of 11,186 firms across African and Asian countries controlling for firm, country, and time characteristics. In our main specification, we find that SEZ firms are on average $4.2 \%$ more electricity intensive than their non-SEZ counterparts. In order to provide insight into what may be driving this higher energy intensity, we undertake several additional robustness checks. First, we omit the foreign-owned firms, something which does not affect the SEZ result. This suggests that the difference is not driven by multinationals seeking low environmental regulation hosts. Second, we exploit cross-country and cross-firm variation in measures related to regulation and barriers to doing business. The rationale behind this is derived from studies such as Bagayev (2015), which finds that access to finance has a significant impact on the pollution intensity of Eastern European exports, potentially via firms' ability to upgrade their technology. Using firm level data for Central European and Central Asian countries, Bagayev and Najman (2012) similarly find that country financial development has a significant effect on firm-level energy intensity. Trianni and Cagno (2012) find similar effects for Italy while Fafchamps and Schundeln (2013) do so for Morocco. Other studies consider factors such as government and business regulations (Cling and Letilly, 2001), imperfect information (Gillingham and Palmer, 2014), and infrastructure (Peterson and Rajan, 2002) with regards to the energy intensity for manufacturing firms (although none these studies specifically consider SEZs). In particular, we find that greater regulatory burdens and greater financial barriers increase the electricity intensity of SEZ relative to non-SEZ firms. This latter result

\footnotetext{
${ }^{3}$ Hanna (2010) find that energy intensive US multinationals relocate their production to developing countries with weak environmental regulations.
} 
is telling as, in our data, non-SEZ firms more often indicate that financial barriers are a detriment to doing business than do SEZ firms. Thus, SEZ firms, particularly when funding is difficult to obtain, may be more apt to upgrade their technology. This suggests that the effect of SEZs may be coming from such firms having more modern, yet more electricity intensive, production methods.

It should be noted, however, that even if electricity intensity is higher for SEZ firms, this does not necessarily translate into higher emissions and lower environmental quality. More advanced technologies, although requiring more energy, may also result in less emissions from that energy use. In addition, if the effect comes from a shift from coal or oil burning towards electricity, this too can lower the environmental impact of higher energy use. Finally, if SEZs have superior infrastructure that allows firms to rely on centrally-provided electricity as opposed to their own generators, this can also offset the environmental damages or greater electricity intensity.

The rest of the paper is organised as follows. Section 2 provides a statistical description and correlation analyses of data. Section 3 describes our empirical model and regression results. Section 4 provides a brief summary and draws conclusions.

\section{Data and Summary Statistics}

In this section, we describe our data and make some preliminary comparisons between SEZ and non-SEZ firms.

\section{$2.1 \quad$ Data}

Our primary data come from the World Bank's Enterprise Surveys $4^{4}$ Although the bulk of the research uses the standardised version of these surveys, we instead use the more recent

\footnotetext{
${ }^{4}$ These can be found at http://www.enterprisesurveys.org//.
} 
unstandardised versions as they contain information on whether or not firms are in SEZs.5 In some countries, surveys were conducted twice; in these cases we kept the survey with the greatest number of observations. Note that since there is no indication whether a firm was surveyed twice when multiple surveys exist, we cannot use a panel data approach, making our data cross-sectional. We restrict our data to the manufacturing sector only, which is generally seen as being more energy intensive than services ${ }^{6}$ After cleaning, matching, and harmonising the surveys, we were left with 32 surveys covering African and South Asian countries and a total of 11,186 firms. Table 1 lists the countries and years of surveys in our sample, along with the number of SEZ and non-SEZ observations.7 This creates our variable of interest, $S E Z$, which equals 1 for a firm in an SEZ.

Along with SEZ data, surveys contain other information about firms. First, it includes information on the firm's electricity usage and total sales, the ratio of which is our proxy for the electricity intensity of a firm (i.e. the electricity expenditure divided by total sales) $8^{8}$ This measure is commonly used to proxy for energy intensity in the literature (see, e.g. Bagayev (2015) or Batrakova and Davies (2012)) $\}^{9}$ Sales are also used to construct a proxy for labour productivity, which is the ratio of sales to employment 10 In addition, we use employment separately as a proxy of firm size. We also have information the age of the firm and a set of dummy variables indicating when a firm is foreign-owned, multi-product, possesses

\footnotetext{
${ }^{5}$ Some of these surveys only ask whether or not a firm is in an SEZ whereas others distinguish between export processing zones and industrial parks. We do not make use of this distinction as the difference is not obviously comparable across surveys and it would preclude including some countries where the survey does not distinguish between the two. Finally, as some countries do not have surveys including the SEZ question in any form, these were excluded. Unfortunately our data do not indicate which SEZ a firm is in nor what benefits the SEZ provides. Along with that, the surveys do not allow us to learn whether a firm is operating only in a SEZ, or if it has facilities out of the SEZ territory.

${ }^{6}$ Specifically, we use firms with ISIC 3.1 classification codes from 15 to 37 .

${ }^{7}$ Note that roughly half the sample's firms are Indian. When excluding India, results are comparable.

${ }^{8}$ Sales and electricity costs are reported in local currencies. We convert these into constant 2010 US dollars, using the US consumer price index and the official exchange rates obtained from the World Bank's Development Indicators database. Years of all deflator variables correspond with year of enterprise surveys.

${ }^{9}$ We nevertheless acknowledge that as it represents only one type of energy consumption, that it is at best a proxy. In unreported results, rather than measuring electricity intensity as electricity costs relative to sales, comparable to Bagayev (2015) or Weyman-Jones et al. (2015) we use electricity costs relative to total costs. This alternative gave qualitatively identical results which are available on request.

${ }^{10}$ Sales is in millions of constant US dollars. This measure is common in the literature for labour productivity. See for example, Pavcnik (2002).
} 
an international quality certificate, licenses foreign technologies, imports, and exports. In particular, Cole et al. (2006) find that trade openness leads to higher energy intensity. All non-binary firm variables are logged and the summary statistics are found in Table 2 .

As shown by Davies and Mazhikeyev (2015), the impact of SEZs on firm exporting behaviour varies with national characteristics such as government regulation. With that in mind, in addition to firm-level information, we utilize information on at the national level to construct country-specific measures of regulatory, financial and environmental burdens. Data to construct these measures comes from Inter-American Development Bank's DataGob ${ }^{11}$ More specifically, to construct the regulation burden measure (Reg Burden, we used (scale based) indicators of the burden of local government regulation, the business impact of custom procedures, the efficiency of customs procedures, and the organized efforts to improve competitiveness. For the financial regulation burden measure, Fin. Burden, we include data on the inefficiency of the tax system, the irregular payments in loan applications, and the resolutions in courts for overdue payments. For environmental regulation burden measure, Env. Burden, we used the environmental regulation stringency and the sustainable development indicators. All indicators used to construct our regulatory measures are highly and positively correlated with each other, therefore we combine them using principal component analysis so that we have mean zero regulatory measures where higher values indicate a greater burden to doing business. Details of this process are in Table 3 .

As an alternative to these national level measures of regulatory burden, we additionally employ firm-level measures derived from the firm's self-revealed biggest obstacle ${ }^{12}$ Specifically, we construct two dummy variables, the first equal to one for those firms listing access to finance as their largest problem (Firm Fin.) and the second equal to one for firms listing electricity provision as their biggest difficulty (Firm Elec.). In our data, 15.9\% of non-SEZ firms report financial barriers as their greatest problem. In contrast, only $11.8 \%$ of SEZ

\footnotetext{
${ }^{11}$ These are available at http://www.iadb.org/datagob.

${ }^{12}$ Other firm-level responses on the barriers created by factors such as corruption or taxes were also used. These, however, were insignificant and therefore are omitted for space.
} 
firms do so suggesting that these firms typically have better access to funding ${ }^{13}$ Similarly, $23.2 \%$ of non-SEZ firms report electricity as their greatest problem whereas only $16.2 \%$ of SEZ firms do so. Although one might well be concerned with endogeneity in these (i.e. that firms using more electricity find access to electricity their primary difficulty), we utilize them in a subset of our regressions with the caveat that they need to be interpreted in light of that possibility.

\subsection{SEZ vs non-SEZ Firm Characteristics}

In Table 4 we present the means of energy intensity and firm characteristics of those in and outside SEZs (columns 1 and 2). Column 3 presents the difference between the two with the * s indicating the significance of an SEZ dummy variable in a regression also controlling for country, year and industry effects. The final column indicates this estimated difference as a percentage term.

Beginning with the variable of interest, we see that firms in SEZs are more electricity intensive than their non-SEZ counterparts. This difference, however, is not significant. It should be noted, however, that this comparison does not control for other firm-level characteristics. As the rest of the table shows, there are a number of significant differences between SEZ and non-SEZ firms. SEZ firms are larger (in terms of sales and employment), younger, more productive, and more likely to be foreign-owned, have a quality certification, license a foreign technology, export, and import. SEZ firms, on the other hand, are less likely to be multi-product firms.

\section{$3 \quad$ Regression Results}

As noted above, we found no differences in the electricity intensity of SEZ firms. That analysis, however, did not control for other firm characteristics such as size or productivity

\footnotetext{
${ }^{13}$ Indeed, some SEZs include financial sources unavailable to firms outside the zone.
} 
which may influence energy use. Therefore, in this section we turn to regression analysis. Our baseline specification is:

$$
E I_{i}=\beta_{0}+\beta_{1} S E Z_{i}+\beta_{2} Z_{i}+\theta_{j}+\theta_{s}+\theta_{t}+\varepsilon_{i}
$$

where $E I_{i, j, s, t}$ is electricity intensity, $S E Z_{i}$ is a dummy equal to 1 if the firm is in an SEZ, $Z_{i}$ is a vector of controls as discussed above, and the $\theta$ s are a set of country $\gamma^{14}$, sector $s$, and year $t$ dummy variables. These latter serve as fixed effects to control for unobservables factors common across firms in a given country (which are all observed in the same year), common across firms in a given sector, and common to all firms surveyed in a particular year. Because the data come from a stratified survey, we weight the observations according to the strata in the survey, specifically employment in three categories (under 20, 20-99, and 100+) and country 15 Further, we cluster the standard errors by country. As our dependent variable lies between zero and one for all observations, we use OLS rather than the Tobit estimator. To this baseline, as described below, we introduce additional country-level Non-Tariff Measures (NTM).

\subsection{Baseline Results}

Table 5 presents the baseline regression results. Column 1 includes the firm-level controls excluding the SEZ, importer, and exporter dummies. Excepting the licensing of foreign technology, all of these controls are highly significant. In particular, we find that more productive and older firms are less electricity intensive. Note that we are not claiming causation, but merely correlation. The same correlation is true for larger and multi-product firms which may indicate some economies of scale in electricity usage. In contrast, foreignowned firms and those with a quality certificate use more electricity relative to output. As

\footnotetext{
${ }^{14}$ Indian firms comprise over $50 \%$ of total firms, and $66 \%$ of all SEZ firms. Using country fixed effects could be one of the data limitations for this work since the within county heterogeneity for India could be a potential issue that a simple country fixed effect can not control.

${ }^{15}$ See http://www .enterprisesurveys.org/methodology for discussion on the survey stratification.
} 
we are controlling for sector dummies, this may suggest that these firms are making more energy intensive products compared to the average firm in their industry.

Column 2 introduces the SEZ dummy. In contrast to Table 4 we find that after controlling for additional firm-level characteristics, the higher electricity intensity of SEZ firms is significant. In any case, this is consistent with SEZ firms relying more on electricity use due to more reliable provision within the zone, using more modern and energy-intensive technologies, and/or specializing in more energy-intensive products within their sectors. With the exception of age, which is now less significant, introducing the SEZ dummy does not overly affect the other estimates. It is important to recognize that their continued significance, combined with their significant differences between SEZ and non-SEZ firms, is why we now find a significantly higher electricity intensity for SEZ firms whereas we did not in Table 4.

In columns 3 and 4, we introduce the exporter and importer dummies, both on their own and interacted with the SEZ variable (column 4). Firms that export and import have higher electricity intensity. This is consistent with the average exporter effect found by Batrakova and Davies (2012). This difference, however, does not vary with whether or not the firm is in an SEZ. Using the sample average (logged) electricity intensity of -4.097 and the results of our preferred specification in column 3, being located in an SEZ would increase the electricity intensity from -4.097 to -3.923 , an increase of $4.2 \%$.

Finally, in column 5, we omit foreign-owned firms out of concern that for this group, high electricity using firms may be seeking out low regulation countries and the locating within their SEZs. However, as can be seen, omitting these firms does not impact the SEZ coefficient (although it does eliminate the significance of the labour productivity measure).

It is worth commenting that the finding of a positive dummy for foreign ownership may appear to contradict a few previous literature findings: notably Jiang et al (2015) for China and Sahu and Narayanan (Eurasian Journal of Business and Economics, 2011) for India. However, we should note that our results refer to electricity intensity, whereas these other papers refer to overall fuel intensity. Also, our regression includes firm size as a regressor: 
foreign owned firms tend to be larger, and larger firms (irrespective of ownership) tend to be more efficient. This contrasts with the aggregated data used by Jiang et al (2015) in particular, which is not at firm level and does not correct for firm size.

\subsection{Propensity Score Matching}

One possible issue with our estimates is endogeneity, i.e. firms that are more electricity intensive choose to locate within SEZs. In particular, MNEs, which choose their locations in part based on environmental regulatory pressures, may seek out SEZs due to their relatively suitable conditions for importing intermediates and exporting their final products.

In an attempt to examine this, in Table 6 we employ a propensity score matching technique to estimate:

$$
\tau_{A T T}=E I_{S E Z=1, p(X)}\left(E I\left(\left.E X P(1)\right|_{S E Z=1, p(X)}\right)-E I\left(\left.E X P(0)\right|_{S E Z=1, p(X)}\right)\right)
$$

where we estimate the difference in electricity intensity between SEZ firms (i.e. treated group) and non-SEZ firms (i.e. control group) while holding the probability of being in an SEZ constant (following Caliendo and Kopeinig, 2008) 16 As any remaining differences in the productivity of the matched sample of SEZ and non-SEZ firms is attributed to the treatment, it is paramount to ensure that all observable factors influencing the firm's selection into an SEZ as well as the firm's electricity intensity, are controlled for. Although several matching approaches are available, using a caliper of .0001 worked best with respect to the tests of appropriateness. When doing so, we see in Panel A of Table 6 that in both the unmatched and matched sample, there is a significant difference between SEZ and nonSEZ firms. When matching, the size of the difference falls marginally (from -4.02 to -3.99), however there is a large decline in significance (with the associated t-statistic falling from 6.14 to 3.03). Nevertheless, this provides some reassurance that endogeneity is not driving the result. We note that for matching, we use all the firm-level characteristic variables that come

\footnotetext{
${ }^{16}$ We still control for country, sector, and year effects.
} 
from the surveys: namely, Sales, Productivity, Employment, Age, Foreign Owned, Exporter, Importer, Multi-product producer, License and Quality Certificate holder variables. These variables are described in the Data section.

This approach, however, relies on an appropriate matching. With this, there are two factors to consider. First, it relies only on firms for which a match could be found, resulting in only 4044 non-SEZ firms and 2419 SEZ firms for which there was common support (i.e. slightly over half the sample) in Panel C. Second, as shown in Panel B, even after matching, there are some significant differences in size and age. However, as shown in Panel C, the low pseudo- $\mathrm{R}^{2}$ after matching supports the quality of the process. Despite the imbalance in the data, matching with Propensity Score Matching has been able to control for it reasonably. In Figure 1 and 2 we plot the density of treated and control variables in pre-matching and post-matching cases. As can be seen from the pre-matching plot (Figure 1), they are highly differently shaped. But after matching them, control variables been considerably adjusted to meet the density shape of treated ones (Figure 2). Finally, we perform a likelihood test on the joint significance of all the variables included in the probit model before and after matching. Following the same logic, we should expect to reject this test on the matched sample only (Caliendo and Kopeinig, 2008) which is again the case. Thus, these tests support the validity of the matching with these caveats in mind.

\subsection{Coarsened Exact Matching}

We also consider an alternative method of matching - Coarsened Exact Matching (CEM), which is offered by Blackwell et al (2009). This method reduces imbalances in covariates between treated and control groups. King and Nielson (2016) argue that CEM is preferable for data matching, compared to Propensity Score Matching (PSM), because it improves the match and therefore reduces model dependence bias. The match was found for 3170 non-SEZ and 3657 SEZ firms with CEM. Comparing it with PSM matching, the CEM match is lesser for non-SEZ firms and more for SEZ firms but overall the total number of matches is slightly 
larger. There is 1674 non-SEZ and 2685 SEZ firm observations are not comparable, and therefore pruned. Table 7, we present the Coarsened Exact Matching results, which provide important information on imbalances. The overall imbalance is shown by the Multivariate imbalance (L1 in Part A). This is interpreted similarly to the $\mathrm{R}^{2}$ in the PSM that explains the model fit, however, L1 in the CEM explains the imbalance (or balance), after taking into count all interactions and the full joint distribution of covariates. The L1 ranges between 0 and 1 , where $\mathrm{L} 1=0$ means the perfect global balance and $\mathrm{L} 1=1$ means the perfect global imbalance. In this particular matching case, L1 is .859, which is suggesting that there is a high overall imbalance. Part B of the table provides univariate imbalances for each control variable separately (in column with header 'L1'). These are all quite low, since they exclude interactions. Notice that univariate L1s are distinctly higher for continuous variables (lnLP, lnemp and lnage) than for the other variables, which are just binary dummy values $(0,1)$. These relatively higher imbalances are due to the differences in means between treated and control groups. This can be seen from the second column (under header 'mean'). For example, the difference for lnLP is .036 which tells that even after matching with CEM, at the mean level, the productivity of SEZ firms is higher than that of it for non-SEZ firms. The differences by quantiles of distributions in the further columns (labelled as 'min', 25\%, 50\%, $70 \%$ and 'max') also supports that lnLP for matched SEZ and non-SEZ differ in favor of SEZ firms. The differences come positive at least at two quantiles for the employment and the age variables between the groups. Thus, even with alternative matching, we obtain the similar results as with the PSM that there are differences between SEZ and non-SEZ firms.

\subsection{Extended Baseline}

As shown in Davies and Mazhikeyev (2015), the impact of SEZs can depend crucially on the national environment in which they are used. With this in mind, here we extend the baseline equation by interacting measures of local business barriers with the SEZ dummy. When the barrier is at the national level, the impact of the barrier itself is absorbed by the country 
fixed effect, thus we only include the barrier itself when using the ones derived from the World Bank survey's question asking what the firm perceives as its biggest barrier. Thus, the extended baseline is:

$$
E I_{i, j, s, t}=\beta_{0}+\beta_{1} S E Z_{i}+\beta_{2} X_{i / j}+\alpha_{1} S E Z_{i} * X_{i, j}+\beta_{2} Z_{i}+\theta_{j}+\theta_{s}+\theta_{t}+\varepsilon_{i}
$$

where $X_{i / j}$ is the additional NTM (measured at the firm $i$ or the country $j$ level). Note that in this case, the net effect of an SEZ on electricity intensity is $\beta_{1}+\alpha_{1} * X_{i / j}$. That said, since the means of the $X_{j}$ variables are zero by the PCA construction, when using these country-level NTMs, at the sample mean the net impact of an SEZ is simply $\beta_{1}$.

Table 9 presents these results with the different columns utilizing different burden measures. In column 1, we include the interaction between the regulation burden variable and the SEZ variable (again, as the regulation burden is a country-specific measure, its noninteracted effect is absorbed by the country fixed effect). As can be seen, in countries where the regulatory burden is higher, the electricity intensity difference between SEZ and nonSEZ firms is significantly higher. Similarly, the results in column 2 show that the gap is higher in countries where fiscal barriers are large. This might be consistent with SEZ firms in such countries having better access to funding, leading them to upgrade to more modern and energy intensive production methods. In contrast, column 3 indicates that the difference between SEZ and non-SEZ firms does not depend on the environmental stringency of the country in question. This potentially argues against pollution haven concerns based on the fear that the higher SEZ electricity intensity is driven by either more lax regulation in the zones and/or multinationals (which are more common in SEZs) seeking out weak environmental standards.

In the last two specifications, we use the firm-level variable indicating whether they find financial barriers their largest difficulty (column 4) and whether electricity provision is their greatest problem (column 5). Beginning with financial barriers, for firms outside of an SEZ, those listing financial barriers as their greatest problem have lower electricity intensity than 
those that do not. As with column 2, this suggests that financially constrained firms may not be upgrading to more modern, electricity-intensive technologies. For firms in an SEZ, however, the sum of the financial variable and its SEZ interaction cancels out, i.e. for firms within an SEZ, there is no difference in the electricity intensity of those that are severely financially constrained and those that are not. Finally, turning to the electricity variable we see that, for firms outside SEZs, those which report electricity provision as their greatest problem have significantly higher electricity intensity than those that do not. The same is true for firms within SEZs, although that gap is smaller due to the negative coefficient on the interaction term. This result, however, should be interpreted with caution as this electricity variable may well be endogenous, i.e. those firms that are electricity intensive are more apt to report electricity provision as a major issue.

Combining these results indicates that there may well be an important interaction between access to finance and the electricity impact of SEZs. This, combined with the insignificance of the environmental burden interaction suggests that our results may be driven primarily by SEZ firms having more advanced technology that results in higher electricity usage. Recognizing this is important because, if those technologies are cleaner despite their higher energy use, this may alleviate some concerns over the environmental impact of SEZs.

\subsection{Fuel Intensity}

One explanation of the above results is that SEZ firms are able to use more modern technologies which, despite being electricity intensive, may nevertheless be cleaner relative to other technologies that utilize 'dirty' sources of energy such as oil, gas, or coal. That said,

electricity provision itself may come from such dirty energy sources. Indeed, SHIFT (2016) indicates that for the period of our survey data (i.e., 2006-2011 years), in Africa coal burning provides $35-40 \%$ of electricity generation, with another $27-30 \%$ coming from gas. In Asia and Oceania, during the same period, coal generates the majority of electricity (55-59\%) with gas contributing another $15 \%$. 
A related issue is fuel substitution. The electricity use figures are based upon purchases of electricity, and exclude own generation. On the one hand, it is conceivable that SEZ firms higher preference for electricity may also lead to higher own generation by these firms (in which case they will also consume more primary fuels). On the other hand, their electricity purchases may be substituting for other fuels, including other fuels used for own generation.

In an attempt to explore this issue, we replace our dependent variable with fuel intensity, i.e. the cost of fuel over total sales. Note that fuel here is basically fossil fuel (and so excludes purchases of electricity). [17 If SEZ firms higher electricity intensity is due to their greater use of their own power plants, we would anticipate that SEZ firms are also more fuel intensive. With this in mind, Tables 8 and 9 mirror Tables 5 and 7 by estimating the correlation between SEZ status and fuel intensity. As can be seen, the control variables are largely similar as when estimating electricity intensity. One critical difference, however, is that fuel intensity is significantly lower for SEZ firms. Furthermore, the impact of SEZs is not contingent on the financial conditions of countries or whether the firm finds itself financially or energy constrained. This then argues against the idea that SEZ firms are more apt to use a private, and potentially dirty, electricity generation method, and supports the idea that electricity is in fact substituting for fossil fuel use. However, we should also note that Table 11, column 4, finds that difficulty accessing finance reduces consumption of fossil fuels as well as electricity (as shown in Table 9, column 5). We suggest this indicates that capital is a complement to use of fuels in general (probably substituting for other inputs, including labour).

\section{Conclusion}

With growing concern over climate change, an increased focus has been put on production, particularly in developing countries where environmental regulations are relatively lax. Special economic zones form a key part of the evolving manufacturing process in these nations

\footnotetext{
${ }^{17}$ Checked in correspondence with World Bank Statisticians
} 
and their use is rapidly rising. In this study, using firm-level data across Africa and Asia, we provide evidence that SEZs are linked to greater electricity intensity. This, combined with the greater size of SEZ firms, gives some credence to concerns that SEZs may have significant environmental impacts. However, we also find that this difference depends on the ability of firms to access finances (among other regulatory barriers). As such, this difference may be due to SEZ firms using more modern, yet electricity intensive technologies. To the extent that such production methods reduce emissions in other ways, this does not necessarily mean that SEZs increase pollution. Indeed, we do not find evidence that SEZ firms use more fuel than others. Nevertheless, it does point towards the need to be cognizant of potential environmental impacts from the formation of SEZs. 


\section{References}

[1] Aci, W., Feui, S. and Aci, N. 2009. Benchmarking survey of establishments in Batam, Bintan and Karimun Special Economic Zone (BBK SEZ). Survey Report. Asia Competitiveness Institute.

[2] Becker, R. and Henderson, V. 2000. Effects of Air Quality Regulations on Polluting Industries. Journal of Political Economy, 108(2), 379-421.

[3] Broner, F., Bustos, P. and Carvalho, V. 2013. Sources of Comparative Advantage in Polluting Industries. NBER-Summer Institutes Environmental and Energy Economics Workshop.

[4] Bagayev, I. 2015. The Energy-Intensive Legacy in Eastern Europe and Central Asia. PhD Thesis. l'Universit Paris-Est Crteil.

[5] Bagayev, I. and Najman, B. 2012. Electricity (in)efficiency in transition economies: evidence from a firm's survey. Conference paper, the International Conference on Environment and Natural Resources Management in Developing and Transition Economies , CERDI.

[6] Batrakova, S. and Davies, R. B. 2012. Is there an environmental benefit to being an exporter?. Review of World Economy. 148, 449-474.

[7] Caliendo, M. and Kopeinig, S. 2008. Some Practical Guidance for the Implementation of propensity Score Matching. Journal of Economic Surveys. 22(1), pp. 31-72.

[8] Blackwell, M., Iacus, S., King, G. and Parro, G. 2009. cem: Coarsened Exact Matching in Stata. the Stata Journal. 9(4), pp. 524546.

[9] Cling, J. et al. 2005. Export Processing Zones in Madagascar: A Success Story under Threat, World Development, 33 (5), 785803.

[10] Gary King and Richard Nielsen. Why Propensity Scores Should Not Be Used for Matching. Working Paper. Retrieved from http://j.mp/2ovYGsW

[11] CID. 2015. The Atlas of Economic Complexity. Center for International Development. Harvard Kennedy School. Available at http://atlas.cid.harvard.edu/country/cri/

[12] Cole, M. A., Elliott, R. J. R., \& Shimamoto, K. 2006. Globalization, firm-level characteristics and environmental management: A study of Japan. Ecological Economics, $59(3), 312323$.

[13] Davies, R.B. and Mazhikeyev, A. 2015. The Impact of Special Economic Zones on Exporting Behavior. Mimeo.

[14] Din, M. 1994. Export Processing Zones and Backward Linkages. Journal of Development Economics, 43, 369-385.

[15] The Economist. 2015. Political priority, economic gamble. April 4, 2015. 
[16] Eskeland, G. S., \& Harrison, A. E. (2003). Moving to greener pastures? Multinationals and the pollution haven hypothesis. Journal of Development Economics, 70(1), 123.

[17] Fafchamps, M. and M. Schndeln. 2013. Local financial development and firm performance: Evidence from Morocco, Journal of Development Economics 103, 15-28.

[18] Farole, T. 2011. Special Economic Zones in Africa: Comparing Performance and Learning from Global Experiences. The World Bank: Washington D.C.

[19] Greenstone, M. 2002. The impacts of Environmental Regulations on Industrial Activities: Evidence from the 1970 and 1977 Clean Air Act Amendments and the Census of Manufactures. Journal of Political Economy, 110(6), 1175-1219.

[20] Gillingham, K. and Palmer, K. 2014. Bridging the energy effciency gap: Policy insights from economic theory and empirical evidence, Review of Environmental Economics and Policy 8(1), 18-38.

[21] Hamilton, C. and Svennson, L. 1982. On the Welfare Effects of a Duty-Free Zone. Journal of international Economics, 13, 45-64.

[22] Hanna, R. 2010. US Environmental Regulation and FDI: Evidence from a Panel of US-Based Multinational Firms. American Economic Journal: Applied Economics, 2, 158-189.

[23] International Labour Office. 1998. Employment and social policy in respect of export processing zones (EPZs). International Labour Office Report GB.286/ESP/3.

[24] Kee, H. L., Nicita, A. and Olarreaga, M. Estimating trade restrictiveness indices, Economic Journal, 2009, 119, 172-199.

[25] KPMG, 2011. Special Economic Zones. Report, KPMG in Poland.

[26] Melitz, M. 2003. The impact of Trade on Intra-Industry Reallocations and Aggregate Industry Productivity. Econometrica, 71(6), 1695-1725.

[27] Milberg, W. \& Amengual, M. 2008. Economic development and working conditions in export processing zones: A survey of trends. International Labour Office Geneva: ILO, 2008

[28] Pavcnik, N. 2002. Trade liberalization, exit and productivity improvements: evidence from Chilean plants. The Review of Economic Studies, 69(1), 245276.

[29] Petersen, M.A. and Rajan, R.G. 2002. Does distance still matter? The information revolution in small business lending, The Journal of Finance, 57(6), 2533-2570.

[30] Roy, J. and Yasar, M. 2015. Energy efficiency and exporting: Evidence from firm-level data, Energy Economics, 52(A), 127-135. 
[31] Trianni, A., Cagno, E., Worrell, E. and Pugliese, G. 2013. Empirical investigation of energy effciency barriers in Italian manufacturing SMEs, Energy Journal, 49(3), 444458.

[32] World Bank. 2008. Special Economic Zones: Performance, Lessons Learned, and Implications for Zone Development. The World Bank: Washington D.C.

[33] Zeng, D.Z. 2015. Global Experiences with Special Economic Zones: Focus on China and Africa. The World Bank: Washington D.C. 
Table 1: Countries in the Sample

\begin{tabular}{|c|c|c|c|}
\hline Country & Num. of Firms & Num. of SEZ firms & Year \\
\hline Afghanistan & 25 & 11 & 2013 \\
\hline Angola & 107 & 21 & 2010 \\
\hline Bangladesh & 1071 & 162 & 2013 \\
\hline Botswana & 75 & 41 & 2010 \\
\hline Burkina Faso & 56 & 25 & 2009 \\
\hline Cameroon & 61 & 18 & 2009 \\
\hline Cabo Verde & 36 & 22 & 2009 \\
\hline Central African Republic & 21 & 10 & 2011 \\
\hline Chad & 34 & 13 & 2009 \\
\hline Congo, Rep. & 6 & 3 & 2008 \\
\hline Congo, Dem. Rep. & 177 & 0 & 2013 \\
\hline Cote d'Ivoire & 122 & 44 & 2008 \\
\hline Eritrea & 41 & 10 & 2009 \\
\hline Ethiopia & 110 & 27 & 2011 \\
\hline Gabon & 12 & 4 & 2008 \\
\hline India & 6332 & 4241 & 2014 \\
\hline Lesotho & 18 & 3 & 2008 \\
\hline Madagascar & 84 & 26 & 2008 \\
\hline Mali & 281 & 281 & 2007 \\
\hline Mauritius & 102 & 25 & 2008 \\
\hline Mozambique & 244 & 244 & 2007 \\
\hline Myanmar & 281 & 0 & 2014 \\
\hline Nepal & 237 & 160 & 2013 \\
\hline Nigeria & 24 & 5 & 2009 \\
\hline Rwanda & 38 & 18 & 2011 \\
\hline Senegal & 170 & 170 & 2007 \\
\hline Sierra Leone & 34 & 4 & 2008 \\
\hline South Africa & 501 & 501 & 2007 \\
\hline Sri Lanka & 303 & 12 & 2011 \\
\hline Tanzania & 180 & 0 & 2013 \\
\hline Uganda & 162 & 0 & 2013 \\
\hline Zambia & 241 & 241 & 2007 \\
\hline Total & 11186 & 6342 & \\
\hline
\end{tabular}


Table 2: Summary Statistics

\begin{tabular}{llllll}
\hline Variable & Obs & Mean & Std. Dev. & Min & Max \\
\hline Electricity Intensity & 11186 & -4.096737 & 1.400718 & -17.53568 & -0.3156215 \\
Productivity & 11186 & 9.834382 & 1.745475 & 2.991356 & 20.28038 \\
Employment & 11186 & 3.643287 & 1.339936 & 0 & 9.21034 \\
Age & 11186 & 2.654669 & 0.8147293 & 0 & 5.241747 \\
Foreign-Owned & 11186 & 0.0574826 & 0.2327728 & 0 & 1 \\
Quality Certificate & 11186 & 0.3558019 & 0.478777 & 0 & 1 \\
Multi-product & 11186 & 0.3881638 & 0.487354 & 0 & 1 \\
License Foreign Tech. & 11186 & 0.1252458 & 0.3310123 & 0 & 1 \\
Importer & 11186 & 0.1497407 & 0.3568331 & 0 & 1 \\
Exporter & 11186 & 0.2007867 & 0.4006067 & 0 & 1 \\
Firm Finance & 11186 & 0.1358841 & 0.3426808 & 0 & 1 \\
Firm Electricity & 11186 & 0.1922045 & 0.3940506 & 0 & 1 \\
Regulatory Barrier & 11098 & $1.41 \mathrm{E}-08$ & 1 & -0.8432723 & 2.699249 \\
Financial Barrier & 11098 & $5.51 \mathrm{E}-09$ & 1 & -0.79444 & 2.846229 \\
Environmental Barrier & 11098 & $-3.28 \mathrm{E}-09$ & 1 & -0.6182633 & 3.704062 \\
\hline
\end{tabular}


Table 3: Construction of Regulation, Finance, and Environmental Burden Variables

Regulatory Burden

\begin{tabular}{lll}
\hline $\begin{array}{l}\text { Observations } \\
\text { Retained Factors } \\
\text { No of Parameters }\end{array}$ & & $\begin{array}{l}11098 \\
1 \\
\end{array}$ \\
\hline & & 4 \\
\hline Factor1 & 3.8763 & 0.9691 \\
Factor2 & 0.09652 & 0.0241 \\
Factor3 & 0.0248 & 0.0062 \\
Factor4 & 0.00237 & 0.0006 \\
Variables & Factor 1 & Uniqueness \\
Local Gov. & 0.9726 & 0.0541 \\
Customs Proc. & 0.9967 & 0.0067 \\
Eff. of Customs & 0.9903 & 0.0193 \\
Competitiveness & 0.9779 & 0.0437 \\
\hline
\end{tabular}

Financial Burden

\begin{tabular}{lll}
\hline $\begin{array}{l}\text { Observations } \\
\text { Retained Factors }\end{array}$ & & $\begin{array}{l}11098 \\
\text { No of Parameters }\end{array}$ \\
\hline & & 3 \\
\hline Factor1 & 2.34622 & 0.7821 \\
Factor2 & 0.51553 & 0.1718 \\
Factor3 & 0.13825 & 0.0461 \\
Variables & Factor 1 & Uniqueness \\
Tax Ineff. & 0.9067 & 0.1779 \\
Irreg. Loan Payment & 0.9444 & 0.1082 \\
Overdue Payment & 0.7952 & 0.3677 \\
\hline & & \\
Environmental Burden & & \\
\hline Observations & & 11098 \\
Retained Factors & & 1 \\
No of Parameters & & 1 \\
\hline & Eigenvalue & Proportion \\
\hline Factor1 & 1.28473 & 0.6424 \\
Factor2 & 0.71527 & 0.3576 \\
Variables & Factor 1 & Uniqueness \\
Env. Reg. & 0.8015 & 0.3576 \\
Sustain. Dev. & 0.8015 & 0.3576 \\
\hline
\end{tabular}


Table 4: SEZ Versus non-SEZ Firms

\begin{tabular}{lllll}
\hline Variable & SEZ & nonSEZ & Difference & Perc. Change \\
\hline Electricity Int. & -4.04 & -4.17 & 0.045 & $4.6 \%$ \\
Sales & 13.93 & 12.88 & $0.538^{* * *}$ & $71.3 \%$ \\
Exporter & 0.20 & 0.20 & $0.042^{* * *}$ & $4.3 \%$ \\
Productivity & 10.20 & 9.35 & $0.202^{* * *}$ & $22.4 \%$ \\
Employment & 3.73 & 3.53 & $0.337^{* * *}$ & $40.1 \%$ \\
Age & 2.62 & 2.69 & $-0.101^{* * *}$ & $-9.6 \%$ \\
Foreign & 0.06 & 0.05 & $0.024^{* * *}$ & $2.4 \%$ \\
Quality Cert. & 0.45 & 0.23 & $0.147^{* * *}$ & $15.8 \%$ \\
Multi-product & 0.37 & 0.42 & $-0.030^{* * *}$ & $-3.0 \%$ \\
License & 0.15 & 0.10 & $0.085^{* * *}$ & $8.9 \%$ \\
Importer & 0.15 & 0.15 & $0.041^{* * *}$ & $4.2 \%$ \\
\hline
\end{tabular}

Notes: Difference is the coefficient on SEZ from a regression using SEZ, country, sector, and year dummies. ***,**, and * denote significance at the $1 \%, 5 \%$, and $10 \%$ levels respectively. Percent change is $100\left(e^{\beta}-1\right)$ where $\beta$ is the SEZ coefficient. 
Table 5: Baseline Regression Results

\begin{tabular}{|c|c|c|c|c|c|}
\hline & $(1)$ & $(2)$ & $(3)$ & $(4)$ & $(5)$ \\
\hline SEZ & & $\begin{array}{c}0.173^{* * *} \\
(0.0281)\end{array}$ & $\begin{array}{c}0.174^{* * *} \\
(0.0280)\end{array}$ & $\begin{array}{c}0.193^{* * *} \\
(0.0299)\end{array}$ & $\begin{array}{c}0.172^{* * *} \\
(0.0282)\end{array}$ \\
\hline Exp*SEZ & & & & $\begin{array}{l}-0.0508 \\
(0.0649)\end{array}$ & \\
\hline Imp*SEZ & & & & $\begin{array}{l}-0.0687 \\
(0.0750)\end{array}$ & \\
\hline Exporter & & & $\begin{array}{c}0.0809 * * \\
(0.0345)\end{array}$ & $\begin{array}{l}0.113^{* *} \\
(0.0541)\end{array}$ & $\begin{array}{c}-0.478^{* * *} \\
(0.0139)\end{array}$ \\
\hline Importer & & & $\begin{array}{c}0.200^{* * *} \\
(0.0405)\end{array}$ & $\begin{array}{c}0.240^{* * *} \\
(0.0609)\end{array}$ & $\begin{array}{c}-0.174^{* * *} \\
(0.0114)\end{array}$ \\
\hline Productivity & $\begin{array}{c}-0.483^{* * *} \\
(0.0130)\end{array}$ & $\begin{array}{c}-0.484^{* * *} \\
(0.0130)\end{array}$ & $\begin{array}{c}-0.492^{* * *} \\
(0.0131)\end{array}$ & $\begin{array}{c}-0.492^{* * *} \\
(0.0131)\end{array}$ & $\begin{array}{l}-0.0227 \\
(0.0149)\end{array}$ \\
\hline Employment & $\begin{array}{c}-0.147^{* * *} \\
(0.0106)\end{array}$ & $\begin{array}{c}-0.149 * * * \\
(0.0106)\end{array}$ & $\begin{array}{c}-0.173^{* * *} \\
(0.0114)\end{array}$ & $\begin{array}{c}-0.175^{* * *} \\
(0.0114)\end{array}$ & $\begin{array}{c}0.0758 * * * \\
(0.0272)\end{array}$ \\
\hline Age & $\begin{array}{c}-0.0316^{* *} \\
(0.0147)\end{array}$ & $\begin{array}{c}-0.0256^{*} \\
(0.0147)\end{array}$ & $\begin{array}{c}-0.0297^{* *} \\
(0.0147)\end{array}$ & $\begin{array}{c}-0.0295^{* *} \\
(0.0147)\end{array}$ & $\begin{array}{c}-0.0756^{* * *} \\
(0.0249)\end{array}$ \\
\hline Foreign & $\begin{array}{c}0.199 * * * \\
(0.0652)\end{array}$ & $\begin{array}{c}0.195 * * * \\
(0.0652)\end{array}$ & $\begin{array}{l}0.149 * * \\
(0.0651)\end{array}$ & $\begin{array}{l}0.150^{* *} \\
(0.0651)\end{array}$ & \\
\hline Qual. Cert. & $\begin{array}{c}0.0955^{* * *} \\
(0.0268)\end{array}$ & $\begin{array}{c}0.0810^{* * *} \\
(0.0269)\end{array}$ & $\begin{array}{c}0.0680^{* *} \\
(0.0270)\end{array}$ & $\begin{array}{c}0.0669 * * \\
(0.0270)\end{array}$ & $\begin{array}{l}-0.0277 \\
(0.0371)\end{array}$ \\
\hline Multi-prod. & $\begin{array}{c}-0.0799 * * * \\
(0.0247)\end{array}$ & $\begin{array}{c}-0.0763^{* * *} \\
(0.0247)\end{array}$ & $\begin{array}{c}-0.0768^{* * *} \\
(0.0246)\end{array}$ & $\begin{array}{c}-0.0773^{* * *} \\
(0.0247)\end{array}$ & $\begin{array}{c}0.199^{* * *} \\
(0.0418)\end{array}$ \\
\hline License & $\begin{array}{c}0.00220 \\
(0.0359)\end{array}$ & $\begin{array}{c}-0.0113 \\
(0.0360)\end{array}$ & $\begin{array}{c}-0.0170 \\
(0.0359)\end{array}$ & $\begin{array}{l}-0.0175 \\
(0.0359)\end{array}$ & $\begin{array}{c}0.466 \\
(0.498)\end{array}$ \\
\hline Constant & $\begin{array}{c}3.815^{* * *} \\
(0.222)\end{array}$ & $\begin{array}{c}3.673^{* * *} \\
(0.222)\end{array}$ & $\begin{array}{c}3.834^{* * *} \\
(0.225)\end{array}$ & $\begin{array}{c}3.833^{* * *} \\
(0.226)\end{array}$ & $\begin{array}{c}0.172^{* * *} \\
(0.0282)\end{array}$ \\
\hline Observations & 11,186 & 11,186 & 11,186 & 11,186 & 10,543 \\
\hline R-squared & 0.333 & 0.336 & 0.338 & 0.338 & 0.328 \\
\hline
\end{tabular}

Notes: $* * *, * *$, and $*$ on difference denote significance at the $1 \%, 5 \%$, and $10 \%$ levels respectively. Country, industry and year dummies included in all specifications. Robust standard errors clustered by country in parentheses.

Figure 1: Propensity Scores before matching

Figure 2: Propensity Scores after matching 
Table 6: Propensity Score Matching: Electricity Intensity

Panel A: Selection

\begin{tabular}{lllllll}
\hline Variable & Sample & Treated & Controls & Difference & S.E. & T-stat \\
\hline Elec. Int. & Unmatched & -4.021 & -4.202 & 0.181 & 0.029 & 6.14 \\
& ATT & -3.999 & -4.154 & 0.154 & 0.051 & 3.03
\end{tabular}

Panel B: Sensitivity Test

\begin{tabular}{|c|c|c|c|c|c|c|}
\hline Variable & Sample & Treated & Control & \%bias & t-test & Prob. Val. \\
\hline $\begin{array}{l}\text { Productivity } \\
\end{array}$ & Unmatched & 10.167 & 9.5103 & 47 & 22.3 & 0 \\
\hline Productivity & Matched & 10.071 & 10.104 & -2.4 & -0.87 & 0.383 \\
\hline Employment & Unmatched & 3.8786 & 3.584 & 22.4 & 10.63 & 0 \\
\hline Employment & Matched & 3.7944 & 3.8789 & -6.4 & -2.25 & 0.025 \\
\hline Age & Unmatched & 2.7038 & 2.7395 & -4.5 & -2.14 & 0.033 \\
\hline Age & Matched & 2.7282 & 2.7805 & -6.6 & -2.31 & 0.021 \\
\hline Foreign & Unmatched & 0.03588 & 0.04105 & -2.7 & -1.27 & 0.205 \\
\hline Foreign & Matched & 0.03592 & 0.03509 & 0.4 & 0.16 & 0.876 \\
\hline Qual. Cert. & Unmatched & 0.5158 & 0.25247 & 56.2 & 26.3 & 0 \\
\hline Qual. Cert. & Matched & 0.45781 & 0.4787 & -4.5 & -1.45 & 0.148 \\
\hline Multi-prod. & Unmatched & 0.26972 & 0.3954 & -26.9 & -12.73 & 0 \\
\hline Multi-prod & Matched & 0.27444 & 0.29574 & -4.6 & -1.63 & 0.103 \\
\hline License & Unmatched & 0.13986 & 0.08828 & 16.3 & 7.59 & 0 \\
\hline License & Matched & 0.10777 & 0.09733 & 3.3 & 1.19 & 0.234 \\
\hline Importer & Unmatched & .12742 & .13848 & -3.3 & -1.54 & 0.125 \\
\hline Importer & Matched & .12112 & .12154 & -0.196 .3 & -0.04 & 0.965 \\
\hline Exporter & Unmatched & .20367 & . 19189 & 3.0 & 1.39 & 0.164 \\
\hline Exporter & Matched & .19016 &. .2038 & -3.4 & -1.19 & 0.233 \\
\hline \multicolumn{7}{|c|}{ Panel C: psmatch2 common support } \\
\hline & off support & on support & & & & \\
\hline All & 2486 & 6463 & & & & \\
\hline Untreated & 0 & 4044 & & & & \\
\hline \multirow[t]{4}{*}{ Treated } & 2486 & 2419 & & & & \\
\hline & Sample & Pseudo $\mathrm{R}^{2}$ & LR $\chi^{2}$ & $\mathrm{p}>\chi^{2}$ & Mean Bias & Med. Bias \\
\hline & Unmatched & 0.234 & 2885.7 & 0 & 16.2 & 11.2 \\
\hline & Matched & 0.007 & 47.81 & 0.522 & 2.2 & 1.6 \\
\hline
\end{tabular}


Table 7: The Coarsened Exact Matching

\begin{tabular}{llllllll}
\hline \multicolumn{7}{c}{ Panel A: Matching summary } \\
\hline All & non-SEZ & SEZ \\
Matched & 4844 & 6342 & & & & \\
Unmatched & 3649 & 4607 & & & \\
\hline \multicolumn{7}{c}{ Panel B: Multivariate imbalances } \\
\hline \multicolumn{7}{c}{ L1 } \\
\hline \multicolumn{7}{c}{ Panel C: Univariate imbalances } \\
\hline L1 mean & min & $25 \%$ & $50 \%$ & $75 \%$ & $\max$ \\
lnLP & 0.07 & 0.04 & 0.27 & 0.03 & 0.09 & 0.02 & -0.36 \\
lnemp & 0.03 & 0.00 & - & - & 0.04 & - & 0.21 \\
lnage & 0.05 & 0.01 & - & - & - & 0.04 & 0.04 \\
Foreign10 & 0.00 & 0.00 & - & - & - & - & - \\
qcert & 0.00 & 0.00 & - & - & - & - & - \\
multi & 0.00 & 0.00 & - & - & - & - & - \\
license & 0.00 & 0.00 & - & - & - & - & - \\
import & 0.00 & 0.00 & - & - & - & - & - \\
exporter & 0.00 & 0.00 & - & - & - & - & - \\
\hline
\end{tabular}


Table 8: Baseline Regression with SEZ and Productivity Interacted

\begin{tabular}{|c|c|}
\hline VARIABLES & $\begin{array}{l}(1) \\
\text { lnelecint }\end{array}$ \\
\hline sez & $\begin{array}{l}-0.548^{* *} \\
(0.225)\end{array}$ \\
\hline sez_lnLP & $\begin{array}{l}0.0726^{* * *} \\
(0.0228)\end{array}$ \\
\hline $\operatorname{lnLP}$ & $\begin{array}{l}-0.527 * * * \\
(0.0177)\end{array}$ \\
\hline lnemp & $\begin{array}{l}-0.168^{* * *} \\
(0.0110)\end{array}$ \\
\hline lnage & $\begin{array}{l}-0.0245^{*} \\
(0.0146)\end{array}$ \\
\hline Foreign10 & $\begin{array}{l}0.158 * * \\
(0.0650)\end{array}$ \\
\hline qcert & $\begin{array}{l}0.0689 * * \\
(0.0269)\end{array}$ \\
\hline multi & $\begin{array}{l}-0.0732^{* * *} \\
(0.0247)\end{array}$ \\
\hline license & $\begin{array}{c}-0.00906 \\
(0.0359)\end{array}$ \\
\hline import & $\begin{array}{l}0.219^{* * *} \\
(0.0399)\end{array}$ \\
\hline Constant & $\begin{array}{l}3.919 * * * \\
(0.229)\end{array}$ \\
\hline Observations & 11,186 \\
\hline R-squared & 0.339 \\
\hline
\end{tabular}

Notes: ***, **, and $*$ on difference denote significance at the $1 \%, 5 \%$, and $10 \%$ levels respectively. Country, industry and year dummies included in all specifications. Robust standard errors clustered by country in parentheses. 
Table 9: Extended Baseline Regression Results

\begin{tabular}{|c|c|c|c|c|c|}
\hline VARIABLES & $\begin{array}{l}(1) \\
\text { lnelecint }\end{array}$ & $\begin{array}{l}(2) \\
\text { lnelecint }\end{array}$ & $\begin{array}{l}(3) \\
\text { lnelecint }\end{array}$ & $\begin{array}{l}(5) \\
\text { lnelecint }\end{array}$ & $\begin{array}{l}(6) \\
\text { lnelecint }\end{array}$ \\
\hline sez & $\begin{array}{l}-0.551^{* *} \\
(0.223)\end{array}$ & $\begin{array}{l}-0.541^{* *} \\
(0.223)\end{array}$ & $\begin{array}{l}-0.488^{* *} \\
(0.220)\end{array}$ & $\begin{array}{l}-0.632^{\text {**** }} \\
(0.228)\end{array}$ & $\begin{array}{l}-0.492^{* *} \\
(0.224)\end{array}$ \\
\hline sez_lnlp & $\begin{array}{l}0.0739^{* * *} \\
(0.0227)\end{array}$ & $\begin{array}{l}0.0734^{* * *} \\
(0.0227)\end{array}$ & $\begin{array}{l}0.0649^{* * *} \\
(0.0222)\end{array}$ & $\begin{array}{l}0.0779 * * * \\
(0.0230)\end{array}$ & $\begin{array}{l}0.0707^{* * *} \\
(0.0227)\end{array}$ \\
\hline $\operatorname{lnLP}$ & $\begin{array}{l}-0.519^{* * *} \\
(0.0167)\end{array}$ & $\begin{array}{l}-0.519^{* * *} \\
(0.0167)\end{array}$ & $\begin{array}{l}-0.514^{* * *} \\
(0.0164)\end{array}$ & $\begin{array}{l}-0.524^{* * *} \\
(0.0178)\end{array}$ & $\begin{array}{l}-0.519 * * * \\
(0.0176)\end{array}$ \\
\hline lnemp & $\begin{array}{l}-0.152^{* * *} \\
(0.0106)\end{array}$ & $\begin{array}{l}-0.152^{* * *} \\
(0.0106)\end{array}$ & $\begin{array}{l}-0.151^{* * *} \\
(0.0106)\end{array}$ & $\begin{array}{l}-0.154^{* * *} \\
(0.0106)\end{array}$ & $\begin{array}{l}-0.152^{* * *} \\
(0.0106)\end{array}$ \\
\hline lnage & $\begin{array}{l}-0.0222 \\
(0.0147)\end{array}$ & $\begin{array}{l}-0.0223 \\
(0.0147)\end{array}$ & $\begin{array}{l}-0.0218 \\
(0.0147)\end{array}$ & $\begin{array}{l}-0.0240 \\
(0.0146)\end{array}$ & $\begin{array}{l}-0.0202 \\
(0.0146)\end{array}$ \\
\hline Foreign10 & $\begin{array}{l}0.205^{* * *} \\
(0.0653)\end{array}$ & $\begin{array}{l}0.206^{* * *} \\
(0.0653)\end{array}$ & $\begin{array}{l}0.214^{* * *} \\
(0.0654)\end{array}$ & $\begin{array}{l}0.194^{* * *} \\
(0.0651)\end{array}$ & $\begin{array}{l}0.197^{* * *} \\
(0.0652)\end{array}$ \\
\hline qcert & $\begin{array}{l}0.0828^{* * *} \\
(0.0269)\end{array}$ & $\begin{array}{l}0.0828^{* * *} \\
(0.0269)\end{array}$ & $\begin{array}{l}0.0807^{* * *} \\
(0.0269)\end{array}$ & $\begin{array}{l}0.0746^{* * *} \\
(0.0270)\end{array}$ & $\begin{array}{l}0.0780^{* * *} \\
(0.0270)\end{array}$ \\
\hline multi & $\begin{array}{l}-0.0703^{* * *} \\
(0.0247)\end{array}$ & $\begin{array}{l}-0.0704^{* * *} \\
(0.0247)\end{array}$ & $\begin{array}{l}-0.0713^{* * *} \\
(0.0247)\end{array}$ & $\begin{array}{l}-0.0725^{* * *} \\
(0.0247)\end{array}$ & $\begin{array}{l}-0.0735^{* * *} \\
(0.0247)\end{array}$ \\
\hline license & $\begin{array}{c}-0.00489 \\
(0.0356)\end{array}$ & $\begin{array}{c}-0.00454 \\
(0.0356)\end{array}$ & $\begin{array}{c}-0.00448 \\
(0.0356)\end{array}$ & $\begin{array}{c}-0.00632 \\
(0.0359)\end{array}$ & $\begin{array}{c}-0.00494 \\
(0.0359)\end{array}$ \\
\hline rb_sez & $\begin{array}{l}0.115^{* * *} \\
(0.0364)\end{array}$ & & & & \\
\hline fb_sez & & $\begin{array}{l}0.107^{* * *} \\
(0.0348)\end{array}$ & & & \\
\hline ob_sez & & & $\begin{array}{l}0.110^{* *} \\
(0.0462)\end{array}$ & & \\
\hline fin_sez & & & & $\begin{array}{l}0.264^{* * *} \\
(0.0657)\end{array}$ & \\
\hline finance & & & & $\begin{array}{l}-0.243^{* * *} \\
(0.0510)\end{array}$ & \\
\hline elc_sez & & & & & $\begin{array}{l}-0.185^{* * *} \\
(0.0563)\end{array}$ \\
\hline electr & & & & & $\begin{array}{l}0.269 * * * \\
(0.0413)\end{array}$ \\
\hline Constant & $\begin{array}{l}0.531 \\
(0.451)\end{array}$ & $\begin{array}{l}0.521 \\
(0.451)\end{array}$ & $\begin{array}{l}0.502 \\
(0.450)\end{array}$ & $\begin{array}{l}3.892^{* * *} \\
(0.230)\end{array}$ & $\begin{array}{l}3.741^{* * *} \\
(0.227)\end{array}$ \\
\hline Observations & 11,098 & 11,098 & 11,098 & 11,186 & 11,186 \\
\hline R-squared & 0.327 & 0.327 & 0.326 & 0.338 & 0.340 \\
\hline
\end{tabular}

Notes: ${ }^{* * *},{ }^{* *}$, and ${ }^{*}$ on difference denote significance at the $1 \%, 5 \%$, and $10 \%$ levels respectively. Country, industry and year dummies included in all specifications. Robust standard errors clustered by country in parentheses. 
Table 10: Baseline Regression Results with Fuel Intensity Measure

\begin{tabular}{|c|c|c|c|c|}
\hline VARIABLES & $\begin{array}{l}(1) \\
\text { lnfuelint }\end{array}$ & $\begin{array}{l}(2) \\
\text { lnfuelint }\end{array}$ & $\begin{array}{l}(3) \\
\text { lnfuelint }\end{array}$ & $\begin{array}{l}(4) \\
\text { lnfuelint }\end{array}$ \\
\hline expsez & & & & $\begin{array}{l}0.0389 \\
(0.0826)\end{array}$ \\
\hline impsez & & & & $\begin{array}{l}-0.280^{* * *} \\
(0.0924)\end{array}$ \\
\hline exporter & & & $\begin{array}{l}0.00666 \\
(0.0440)\end{array}$ & $\begin{array}{l}-0.0125 \\
(0.0682)\end{array}$ \\
\hline import & & & $\begin{array}{l}0.199 * * * \\
(0.0505)\end{array}$ & $\begin{array}{l}0.362^{* * *} \\
(0.0755)\end{array}$ \\
\hline sez_lnLP & & $\begin{array}{l}0.0343 \\
(0.0267)\end{array}$ & $\begin{array}{l}0.0351 \\
(0.0267)\end{array}$ & $\begin{array}{l}0.0409 \\
(0.0267)\end{array}$ \\
\hline sez & & $\begin{array}{c}-0.478^{*} \\
(0.265)\end{array}$ & $\begin{array}{c}-0.483^{*} \\
(0.265)\end{array}$ & $\begin{array}{c}-0.511^{*} \\
(0.264)\end{array}$ \\
\hline $\operatorname{lnLP}$ & $\begin{array}{l}-0.484^{* * *} \\
(0.0143)\end{array}$ & $\begin{array}{l}-0.501^{* * *} \\
(0.0204)\end{array}$ & $\begin{array}{l}-0.507^{* * *} \\
(0.0205)\end{array}$ & $\begin{array}{l}-0.510^{* * *} \\
(0.0204)\end{array}$ \\
\hline lnemp & $\begin{array}{l}-0.140^{* * *} \\
(0.0138)\end{array}$ & $\begin{array}{l}-0.139 * * * \\
(0.0138)\end{array}$ & $\begin{array}{l}-0.155^{* * *} \\
(0.0146)\end{array}$ & $\begin{array}{c}-0.158^{* * *} \\
(0.0147)\end{array}$ \\
\hline lnage & $\begin{array}{l}-0.0233 \\
(0.0196)\end{array}$ & $\begin{array}{l}-0.0274 \\
(0.0196)\end{array}$ & $\begin{array}{l}-0.0298 \\
(0.0196)\end{array}$ & $\begin{array}{l}-0.0294 \\
(0.0196)\end{array}$ \\
\hline Foreign10 & $\begin{array}{l}0.174^{* *} \\
(0.0758)\end{array}$ & $\begin{array}{l}0.177^{* *} \\
(0.0757)\end{array}$ & $\begin{array}{l}0.139^{*} \\
(0.0766)\end{array}$ & $\begin{array}{l}0.144^{*} \\
(0.0764)\end{array}$ \\
\hline qcert & $\begin{array}{l}-0.000955 \\
(0.0344)\end{array}$ & $\begin{array}{l}0.00689 \\
(0.0345)\end{array}$ & $\begin{array}{r}-0.00198 \\
(0.0347)\end{array}$ & $\begin{array}{r}-0.00561 \\
(0.0347)\end{array}$ \\
\hline multi & $\begin{array}{l}-0.0346 \\
(0.0316)\end{array}$ & $\begin{array}{l}-0.0357 \\
(0.0317)\end{array}$ & $\begin{array}{l}-0.0353 \\
(0.0316)\end{array}$ & $\begin{array}{l}-0.0365 \\
(0.0316)\end{array}$ \\
\hline license & $\begin{array}{l}0.139 * * * \\
(0.0461)\end{array}$ & $\begin{array}{l}0.153^{* * *} \\
(0.0461)\end{array}$ & $\begin{array}{l}0.152^{* * *} \\
(0.0460)\end{array}$ & $\begin{array}{l}0.155^{* * *} \\
(0.0461)\end{array}$ \\
\hline Constant & $\begin{array}{l}0.372 \\
(0.336)\end{array}$ & $\begin{array}{l}0.530 \\
(0.362)\end{array}$ & $\begin{array}{l}0.627^{*} \\
(0.363)\end{array}$ & $\begin{array}{l}0.623^{*} \\
(0.364)\end{array}$ \\
\hline Observations & 8,389 & 8,389 & 8,389 & 8,389 \\
\hline R-squared & 0.278 & 0.280 & 0.281 & 0.282 \\
\hline
\end{tabular}

Notes: $* * *, * *$, and $*$ on difference denote significance at the $1 \%, 5 \%$, and $10 \%$ levels respectively. Country, industry and year dummies included in all specifications. Robust standard errors clustered by country in parentheses. 
Table 11: Extended Baseline Regression Results Fuel Intensity Measure

\begin{tabular}{|c|c|c|c|c|c|}
\hline VARIABLES & $\begin{array}{l}(1) \\
\text { lnfuelint }\end{array}$ & $\begin{array}{l}(2) \\
\text { lnfuelint }\end{array}$ & $\begin{array}{l}(3) \\
\text { lnfuelint }\end{array}$ & $\begin{array}{l}(4) \\
\text { lnfuelint }\end{array}$ & $\begin{array}{l}5) \\
\text { lnfuelint }\end{array}$ \\
\hline sez & $\begin{array}{c}-0.498^{*} \\
(0.267)\end{array}$ & $\begin{array}{c}-0.500^{*} \\
(0.266)\end{array}$ & $\begin{array}{l}-0.480^{*} \\
(0.265)\end{array}$ & $\begin{array}{c}-0.475^{*} \\
(0.267)\end{array}$ & $\begin{array}{c}-0.479^{*} \\
(0.265)\end{array}$ \\
\hline sez_lnLP & $\begin{array}{l}0.0371 \\
(0.0271)\end{array}$ & $\begin{array}{l}0.0377 \\
(0.0271)\end{array}$ & $\begin{array}{l}0.0342 \\
(0.0267)\end{array}$ & $\begin{array}{l}0.0342 \\
(0.0269)\end{array}$ & $\begin{array}{l}0.0342 \\
(0.0267)\end{array}$ \\
\hline $\operatorname{lnLP}$ & $\begin{array}{l}-0.503^{* * *} \\
(0.0207)\end{array}$ & $\begin{array}{l}-0.504^{* * *} \\
(0.0207)\end{array}$ & $\begin{array}{l}-0.501^{* * *} \\
(0.0204)\end{array}$ & $\begin{array}{l}-0.504^{* * *} \\
(0.0205)\end{array}$ & $\begin{array}{l}-0.501^{* * *} \\
(0.0204)\end{array}$ \\
\hline $\operatorname{lnemp}$ & $\begin{array}{l}-0.139 * * * \\
(0.0138)\end{array}$ & $\begin{array}{l}-0.140^{* * *} \\
(0.0138)\end{array}$ & $\begin{array}{l}-0.139 * * * \\
(0.0138)\end{array}$ & $\begin{array}{l}-0.143^{* * *} \\
(0.0138)\end{array}$ & $\begin{array}{l}-0.139^{* * *} \\
(0.0138)\end{array}$ \\
\hline lnage & $\begin{array}{l}-0.0279 \\
(0.0196)\end{array}$ & $\begin{array}{l}-0.0281 \\
(0.0196)\end{array}$ & $\begin{array}{l}-0.0278 \\
(0.0196)\end{array}$ & $\begin{array}{l}-0.0279 \\
(0.0196)\end{array}$ & $\begin{array}{l}-0.0270 \\
(0.0196)\end{array}$ \\
\hline Foreign10 & $\begin{array}{l}0.174^{* *} \\
(0.0756)\end{array}$ & $\begin{array}{l}0.174^{* *} \\
(0.0756)\end{array}$ & $\begin{array}{l}0.178^{* *} \\
(0.0758)\end{array}$ & $\begin{array}{l}0.174^{* *} \\
(0.0757)\end{array}$ & $\begin{array}{l}0.177^{* *} \\
(0.0757)\end{array}$ \\
\hline qcert & $\begin{array}{l}0.00795 \\
(0.0346)\end{array}$ & $\begin{array}{l}0.00817 \\
(0.0346)\end{array}$ & $\begin{array}{l}0.00724 \\
(0.0345)\end{array}$ & $\begin{array}{l}0.00842 \\
(0.0345)\end{array}$ & $\begin{array}{l}0.00677 \\
(0.0346)\end{array}$ \\
\hline multi & $\begin{array}{l}-0.0353 \\
(0.0317)\end{array}$ & $\begin{array}{l}-0.0352 \\
(0.0317)\end{array}$ & $\begin{array}{l}-0.0356 \\
(0.0317)\end{array}$ & $\begin{array}{l}-0.0331 \\
(0.0316)\end{array}$ & $\begin{array}{l}-0.0356 \\
(0.0317)\end{array}$ \\
\hline license & $\begin{array}{l}0.153^{* * *} \\
(0.0462)\end{array}$ & $\begin{array}{l}0.154^{* * *} \\
(0.0462)\end{array}$ & $\begin{array}{l}0.153^{* * *} \\
(0.0462)\end{array}$ & $\begin{array}{l}0.146 * * * \\
(0.0462)\end{array}$ & $\begin{array}{l}0.152^{* * *} \\
(0.0462)\end{array}$ \\
\hline rb_sez & $\begin{array}{l}0.0414 \\
(0.0487)\end{array}$ & & & & \\
\hline fb_sez & & $\begin{array}{l}0.0499 \\
(0.0465)\end{array}$ & & & \\
\hline ob_sez & & & $\begin{array}{l}0.0407 \\
(0.0622)\end{array}$ & & \\
\hline fin_sez & & & & $\begin{array}{l}-0.00490 \\
(0.0957)\end{array}$ & \\
\hline finance & & & & $\begin{array}{l}-0.186^{* * *} \\
(0.0708)\end{array}$ & \\
\hline elc_sez & & & & & $\begin{array}{l}0.0157 \\
(0.0723)\end{array}$ \\
\hline electr & & & & & $\begin{array}{l}0.00879 \\
(0.0541)\end{array}$ \\
\hline Constant & $\begin{array}{l}1.559^{* * *} \\
(0.250)\end{array}$ & $\begin{array}{l}0.558 \\
(0.364)\end{array}$ & $\begin{array}{l}1.180^{* * *} \\
(0.293)\end{array}$ & $\begin{array}{l}0.612^{*} \\
(0.367)\end{array}$ & $\begin{array}{l}0.528 \\
(0.362)\end{array}$ \\
\hline Observations & 8,389 & 8,389 & 8,389 & 8,389 & 8,389 \\
\hline R-squared & 0.280 & 0.280 & 0.280 & 0.281 & 0.280 \\
\hline
\end{tabular}

Notes: ${ }^{* * *},{ }^{* *}$, and $*$ on difference denote significance at the $1 \%, 5 \%$, and $10 \%$ levels respectively. Country, industry and year dummies included in all specifications. Robust standard errors clustered by country in parentheses. 